\title{
Optimization and Validation of a Real Time Reverse Transcriptase Polymerase Chain Reaction with RNA Internal Control to Detect Rubella RNA
}

\author{
Winny Xie ${ }^{1, *}$, Yusmiati Liau ${ }^{1}$ \\ ${ }^{1}$ Prodia Clinical Laboratory, Jl. Kramat Raya No.150, Jakarta, Indonesia \\ *Corresponding author. E-mail: winny@prodia.co.id
}

\section{Abstract}

$\mathrm{B}$ ACKGROUND: According to a report from WHO, cases of rubella infection in Indonesia has increased up to 10-fold from 2007 to 2011. Despite no data of congenital rubella syndrome in the report, there are approximately 45,000 cases of babies born with heart failure and $0.1-0.3 \%$ live births with congenital deafness in Indonesia. Allegedly, rubella infection during pregnancy may play a role in this condition. This study aimed to optimize and validate a real-time reverse transcriptase polymerase chain reaction (RT-qPCR) method to detect rubella virus RNA as an aid for the diagnosis of congenital rubella infection.

METHODS: Method optimization was conducted using nucleic acids extracted from Trimovax Merieux vaccine with the High Pure Viral Nucleic Acid Kit. One step RTqPCR was performed with Quantifast Multiplex RTPCR + R Kit. Target synthetic DNA was designed and used to determine the sensitivity of the method. RNA internal control was synthesized to control the process of extraction and amplification.

RESULTS: The analytical sensitivity of this method was as low as 5 copies target synthetic DNA/ $\mu$ l. The mean Coefficient of Variation (CV) \% of the critical threshold $(\mathrm{Ct})$ obtained were $2.71 \%, 1.20 \%, 1.62 \%$, and $1.59 \%$ for within run, between run, between kit lots, and between operators, respectively. Recovery of the target synthetic DNA from amniotic fluid was $100.51 \%$ (by the $\log \operatorname{copies} / \mu \mathrm{l}$ ) at the concentration of $10^{5}$ copies $/ \mu 1$.

CONCLUSION: RT-qPCR is successfully used for the detection of rubella virus RNA in vaccine and synthetic

\section{Abstrak}

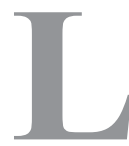

ATAR BELAKANG: Menurut statistik dari WHO, kasus infeksi rubella di Indonesia telah meningkat hingga 10 kali lipat dari tahun 2007 hingga 2011. Meskipun tidak ada laporan sindrom rubella bawaan dalam statistik, di Indonesia saat ini terdapat sekitar 45.000 kasus bayi lahir dengan gagal jantung dan 0,1$0,3 \%$ kelahiran hidup dengan ketulian kongenital. Infeksi rubella selama kehamilan diduga memainkan peran dalam kondisi ini. Penelitian ini bertujuan untuk mengoptimasi dan memvalidasi metode real-time reverse transcriptase polymerase chain reaction (RT-qPCR) untuk mendeteksi RNA virus rubella dalam diagnosis infeksi rubella bawaan.

METODE: Metode optimasi dilakukan dengan menggunakan asam nukleat yang diekstrak dari Trimovax Merieux vaksin dengan High Pure Viral Nucleic Acid Kit. One-Step RT-qPCR dilakukan dengan Quantifast Multiplex RT-PCR $+\mathrm{R}$ Kit. DNA sintetis target dirancang dan digunakan untuk menentukan sensitivitas dari metode ini. Kontrol internal RNA disintesis untuk mengontrol proses transkripsi balik dan amplifikasi.

HASIL: Sensitivitas analitis dari metode ini adalah serendah 5 kopi DNA sintetis target/ $\mu$ l. Rata-rata \% Coefficient of Variation (CV) dari critical threshold (Ct) yang diperoleh berturut-turut adalah 2,71\%, 1,20\%, 1,62\%, dan 1,59\% untuk CV within run, between run, antar-kit, dan antaroperator. Perolehan kembali DNA sintetis target dari cairan

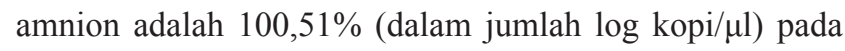
konsentrasi $10^{5} \mathrm{kopi} / \mu \mathrm{l}$.

KESIMPULAN: RT-qPCR berhasil digunakan untuk mendeteksi RNA virus rubella dalam vaksin dan asam 
nucleic acid. With its high sensitivity, good precision and recovery, this method offers a means to improve the diagnosis of congenital rubella infection in developing countries like Indonesia.

KEYWORDS: congenital rubella, RT-qPCR, prenatal diagnosis, amniotic fluid

Indones Biomed J. 2013; 5(3): 185-92 nukleat sintetis. Dengan sensitivitas yang tinggi, serta presisi dan perolehan kembali yang baik, metode ini menawarkan suatu cara untuk meningkatkan diagnosis infeksi rubella kongenital di negara-negara berkembang seperti Indonesia.

KATA KUNCI: rubella bawaan, RT-qPCR, diagnosis prenatal, cairan amnion

\section{Introduction}

Rubella virus (RV) infection is usually present as a mild, asymptomatic and self-limiting illness. However, primary $\mathrm{RV}$ infection during the first trimester of pregnancy leads to severe consequences, such as miscarriage, still birth and congenital rubella syndrome (CRS). Infants born with congenital rubella syndrome can suffer from deafness, blindness, heart defects, mental retardation, microcephaly and other serious health problems. Developmental and lateonset abnormalities may occur due to the progress of CRS. $(1-4)$

In 2003 it was estimated that more than 100,000 infants were born with CRS annually worldwide. CRS cases in American and European region have been reduced significantly through the vaccination program. (5) Developing countries such as Indonesia which have not incorporated rubella-containing vaccines into routine national immunization programs have a great risk of RV transmission. Despite the relatively high risk of rubella infection in Indonesia, no data are available on cases of CRS.(6) This is likely due to a lack of adequate prenatal and postnatal diagnosis to detect rubella infection during pregnancy and after delivery.

Prenatal diagnosis of RV infection is needed to prevent greater damage to the fetus. Meanwhile postnatal diagnosis is important to prevent further spread of the virus as the infants with congenital infection are likely to shed high concentrations of RV for long period. It is particularly important that pregnant women who are not rubella-immune not be exposed to infants with congenital rubella infection (3).

Currently the diagnosis of rubella infection during pregnancy in Indonesia is based only on the detection of rubella specific anti-IgM and IgG antibodies and their avidity of the mother. The results of these tests are not reliable for the diagnosis of rubella infection in the fetus because of a possibility of false positive IgM result (4). Rubella-specific
IgM may persist for months or years after infection or vaccination. Other than that there is a possibility that a fetus of infected woman is not infected by RV. Therefore a proper prenatal diagnosis using fetal sample is needed to prevent unnecessary termination of pregnancy.

Ready-to-use real-time reverse transcriptase polymerase chain reaction (RT-qPCR) commercial kits are available for the detection of rubella RNA at various sample, however, such kits will require higher cost per test. Therefore, this study was conducted to produce a test with a lower cost.

RV is a single-stranded RNA virus, thus its genome must be transcribed to cDNA before amplification (7-9). In this study, to allow reverse transcription and amplification in one tube, one-step RT-qPCR method was optimized to detect RV RNA. RNA internal control was synthesized to control both reverse transcription and amplification process. Internal controls are crucial for reliable results of a PCR process. Internal control amplification is useful to distinguish whether a negative result is a true negative due to no pathogen in sample or false negative due to failure of the amplification reaction.

\section{Methods}

Method optimization was conducted using nucleic acids extracted from Trimovax Merieux vaccine (Sanofi Pasteur, Lyon, France). Target synthetic DNA was designed and used to determine the sensitivity and precision of the assay. RNA internal control oligonucleotide (RICO) was synthesized and used to control reverse transcription and amplification.

RNA extraction. RNA was extracted from $200 \mu \mathrm{l}$ of Trimovax Merieux vaccine by using a High Pure Viral Nucleic Acid Kit (Roche, Mannheim, Germany), according to the manufacturer's instructions.

RT-qPCR. One step RT-qPCR was performed with Quantifast Multiplex RT-PCR+R Kit (Qiagen, Hilden, 
Germany) to amplify a region in the E1 coding region and a 65-nucleotides RICO. Probe for RICO detection was designed based on potato cytochrome oxidase gene with modification. The $25 \mu \mathrm{l}$ RT-PCR mixture was composed of $2.5 \mu \mathrm{l}$ of RNA template, $12.5 \mu \mathrm{l}$ of $2 \mathrm{x}$ QuantiFast Multiplex RT-PCR Master Mix, $0.25 \mu$ of QuantiFast RT Mix, $0.2 \mu \mathrm{M}$ of forward (RV11) and reverse (RV12) primers, $0.1 \mu \mathrm{M}$ of each probes, $2 \mu \mathrm{l}$ of RICO, and $6.25 \mu \mathrm{l}$ of RNase free water. The RT step was $20 \mathrm{~min}$ at $50^{\circ} \mathrm{C}$ and followed by PCR initial activation step at $95^{\circ} \mathrm{C}$ for $5 \mathrm{~min}$. Amplification was done with 40 cycles of $95^{\circ} \mathrm{C}$ for $15 \mathrm{~s}$ and $60^{\circ} \mathrm{C}$ for $1 \mathrm{~min}$. Negative control (nuclease free water) was included in each run. If negative control was contaminated, all results from the run were discarded.

Production of RICO. The designated synthetic DNA internal control oligonucleotide (ICO) contained a T7 RNA polymerase promoter sequence at the $5^{\prime}$ end, followed by the binding region of target's primer flanking the probebinding regions as described in Figure 3. The ICO was dissolved and diluted to 5000 copies/ $\mu$ l. PCR amplification was conducted to obtain a double-stranded template for T7 transcription. The amplification was performed in Veriti ${ }^{\circledR}$ 96-Well Thermal Cycler (Applied Biosystem, USA) with 25 $\mu 1$ reaction mixtures containing $5 \mu \mathrm{l}$ of 10x PCR buffer, 0.2 $\mu \mathrm{M}$ of T7 and RV12 primers, $5 \mu \mathrm{l}$ of $5 \mathrm{x}$ GC rich solution, 2 $\mathrm{U}$ of FastStart Taq DNA Polymerase, and $1 \mu \mathrm{l}$ of ICO as the PCR template. The thermal cycling was carried out at $95^{\circ} \mathrm{C}$ for $4 \mathrm{~min}, 95^{\circ} \mathrm{C}$ for $30 \mathrm{~s}$, followed by 40 cycles of $95^{\circ} \mathrm{C}$ for $30 \mathrm{~s}, 60^{\circ} \mathrm{C}$ for $30 \mathrm{~s}, 72^{\circ} \mathrm{C}$ for $45 \mathrm{~s}$, and one cycle of $72^{\circ} \mathrm{C}$ for $7 \mathrm{~min}$. The PCR product was purified using High Pure PCR Product Purification Kit (Roche), and approximately $50 \mathrm{ng}$ of the PCR product (based on the measurements with Nanodrop (Thermo Scientific, Waltham, MA, USA) was transcribed with T7 RNA polymerase. The transcription mixture consisted of $2 \mu \mathrm{l}$ of $10 \mathrm{x}$ transcription buffer, $0.5 \mu \mathrm{l}$ of protector RNAse inhibitor (40 U/ $\mu$; Roche), $1 \mu$ l of T7 RNA polymerase ( $20 \mathrm{U} / \mu \mathrm{l}$; Roche), $2 \mu \mathrm{l}$ of of the ribonucleoside triphosphates mixture (containing $10 \mathrm{mM}$ each of ATP, CTP, TTP, and GTP), and was added with water to the volume of $20 \mu \mathrm{l}$. The mixture was incubated at $37{ }^{\circ} \mathrm{C}$ for $2 \mathrm{~h}$. The transcript was diluted $10^{-7}$ in RNase-free water. Purification of the diluted transcript was done by the digestion of $10 \mu \mathrm{l}$ of diluted transcript with DNaseI in a total volume of 100 $\mu l$ that included $9 \mu \mathrm{l}$ of DNAseI (18 U/ $\mu$; High Pure RNA Isolation Kit, Roche) and $81 \mu$ of DNAse incubation buffer for $15 \mathrm{~min}$ at $25^{\circ} \mathrm{C}$. The mixture was incubated for $3 \mathrm{~min}$ at $90{ }^{\circ} \mathrm{C}$ to stop the digestion and stored in aliquots at $-20^{\circ} \mathrm{C}$ as RICO stock solution. The RICO stock solution was tested both with and without reverse transcriptase to verify that it was pure RNA and contain no residual control DNA. The amount of RICO to be used in the assay was determined.

Assessment of limit of detection. Limit of detection was determined by testing the dilution of target synthetic DNA. At first this assay was done in the absence of RICO and a total of approximately 9 replicates of the target synthetic DNA (10 copies $/ \mu 1,100$ copies $/ \mu 1,1,000$ copies $/ \mu 1,10,000$ copies $/ \mu 1$, and 100,000 copies $/ \mu 1$ ) were tested. The next trial was done for approximately 19 replicates of the lower concentrations ( 5 copies/ $\mu \mathrm{l}, 10$ copies/ $\mu 1$, and 100 copies/ $\mu \mathrm{l})$. Lastly, the obtained limit of detection was tested in the present of RICO.

Assessment of Variability. The within-run precision was evaluated on 3 replicates for the low concentration (5 copies/ $\mu \mathrm{l}$ and 10 copies/ $\mu \mathrm{l})$ and high concentration (100,000 copies/ $\mu 1)$ target synthetic DNA within one run. Three experimental runs using the same reagent lot were performed by one operator on three different days to evaluate the betweenrun precision. Variation between operators was assessed by two operators using the same samples. Both performed three different experimental runs using the same reagent lot. A total of two reagent lots were used for the lot-to-lot precision assessment.

Spike recovery. Spike recovery test was done to determine the effect of the constituents of the sample on the results. Target synthetic DNA and vaccine was added into three tubes containing negative amniotic fluid (non-reactive by test for RV RNA) to the concentration of 5 copies/ $\mu 1,10$ copies/ $\mu 1$, and 100,000 copies/ $\mu$ l. Nucleic acid extraction and qPCR amplification were performed for all spiked amniotic fluid.

\section{Results}

One-step RT-qPCR was successfully performed to detect RV RNA, target synthetic DNA, and internal control. The specificity of the primers and probes was assessed using the Basic Local Alignment Search Tool (BLAST) from National Center for Biotechnology Information (NCBI) website. Primers and probes used in this study are listed in Table I. Primers specifically recognized a 185-nucleotide region of E1 gene in the genome of rubella Wistar RA 27/3M strain. Trimovax Merieux vaccine contains not only vaccine strain of RV but also measles virus (Schwarz strain) and mumps virus (Urabe strain AM-9). Therefore during the nucleic acid extraction using High Pure Viral Nucleic 
Table 1. Primer, probe, and controls DNA sequences.

\begin{tabular}{|c|c|c|c|}
\hline Name & Role & Sequence (5'-3') & Length \\
\hline RV11 & Forward primer & CAACACGCCGCACGGACAAC & $20 \mathrm{bp}$ \\
\hline RV12 & Reverse primer & CCACAAGCCGCGAGCAGTCA & $20 \mathrm{bp}$ \\
\hline $\mathrm{T} 7$ & $\mathrm{~T} 7$ promoter primer & CCAAGCTTCTAATACGACTCACTA & $24 \mathrm{bp}$ \\
\hline Aber Probe & Target probe & FAM-AGGTCCAGGTCCCGCCCGAC-BHQ1 & $20 \mathrm{bp}$ \\
\hline COX-Probe & Internal control probe & HEX-TGCTTACGCTGGATGGAATGCCCGC-BHQ1 & $25 \mathrm{bp}$ \\
\hline $\mathrm{ICO}$ & Internal control DNA & $\begin{array}{l}\text { CCAAGCTTCTAATACGACTCACTATAGGGAGACAACACGCCGCACGGACAACGCGGGCA } \\
\text { TTCCATCCAGCGTAAGCATGACTGCTCGCGGCTTGTGG }\end{array}$ & 97 bp \\
\hline $\begin{array}{l}\text { Target } \\
\text { Synthetic } \\
\text { DNA }\end{array}$ & $\begin{array}{l}\text { Synthetic external } \\
\text { control }\end{array}$ & $\begin{array}{l}\text { TTCTGCAACACGCCGCACGGACAACTCGAGGTCCAGGTCCCGCCCGACCCTGGGGACCT } \\
\text { GGTTGAGTACATTATGAACCACACCGGCAATCAGCAGTCCCGGTGGGGCCTCGGGAGCC } \\
\text { CGAATTGCCATGGCCCCGATTGGGCCTCCCCGGTTTGCCAACGCCATTCCCCTGACTGCT } \\
\text { CGCGGCTTGTGGGGGTC }\end{array}$ & $195 \mathrm{bp}$ \\
\hline
\end{tabular}

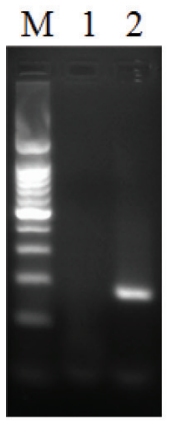

A

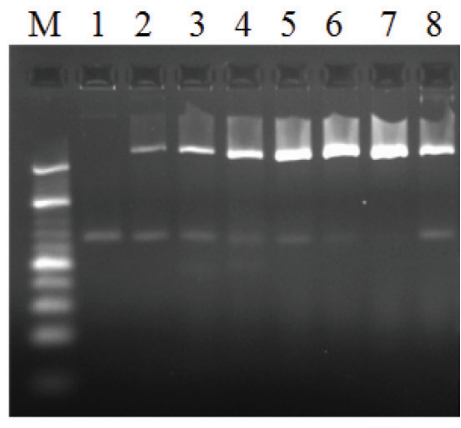

B
Figure 1. Rubella RT-qPCR results on $2 \%$ agarose gel stained with ethidium bromide. (A) RT-qPCR of vaccine extract. Lanes: M, molecular weight marker (100 bp DNA ladder, Promega, USA); 1, negative control; 2, Trimovax Merieux vaccine extract. (B) RT-qPCR of target synthetic DNA and Trimovax Merieux vaccine extract in the presence of RICO. Lanes: M, molecular weight marker (O'RangeRuler 10 bp DNA Ladder, ready-to-use, Fermentas, USA); 1, negative control, 2-7, target synthetic DNA $(5 ; 10 ; 100 ; 1,000 ; 10,000$; and 100,000 copies $/ \mu 1), 8$, Trimovax Merieux vaccine extract.

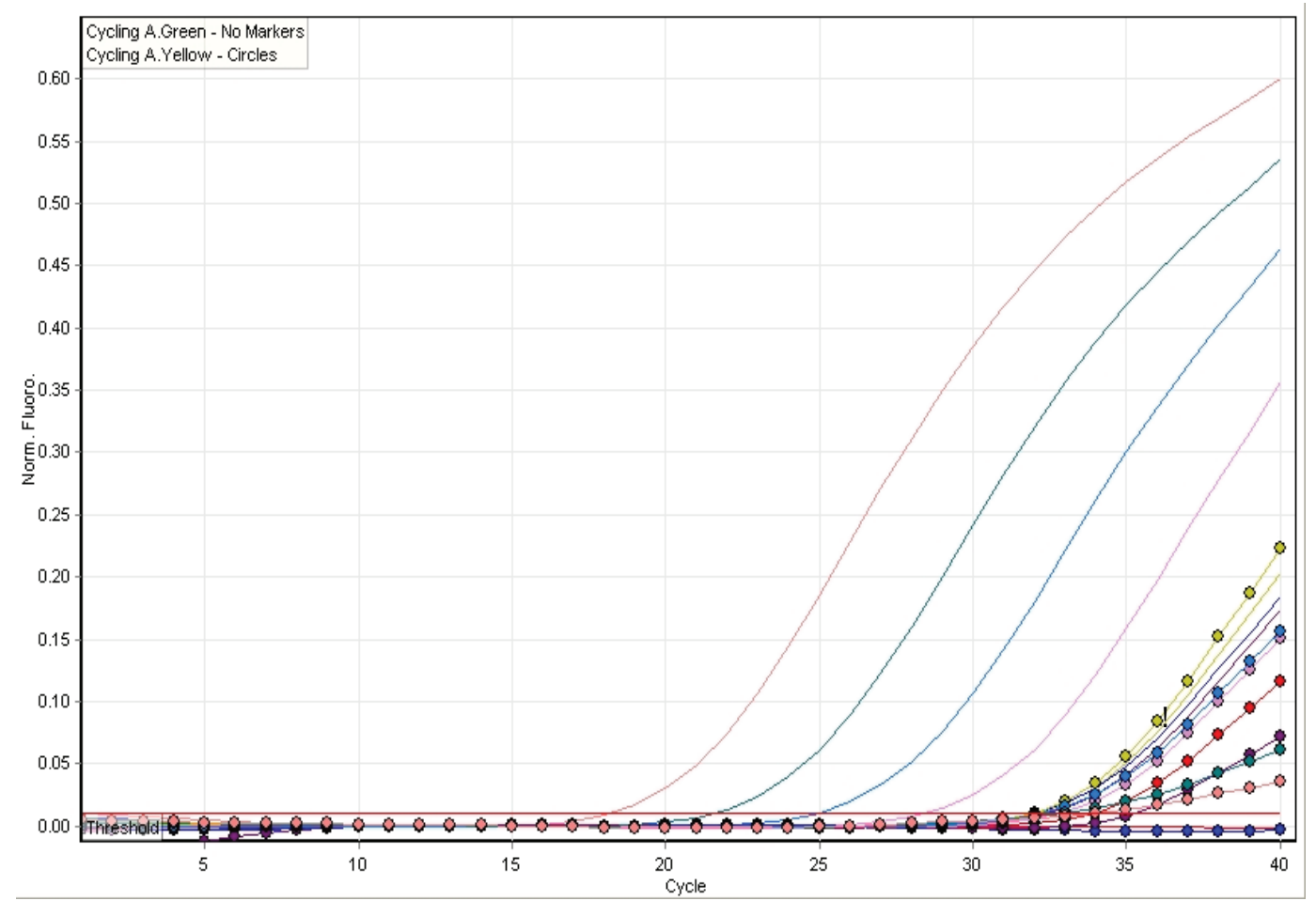

Figure 2. Amplification curves of synthetic external control and RICO in Rotor-Gene Q software. Cycling A. Green (FAM)-No markers: amplification curve of target synthetic DNA; Cycling A. Yellow (HEX)-circles: amplification curve of RICO. 


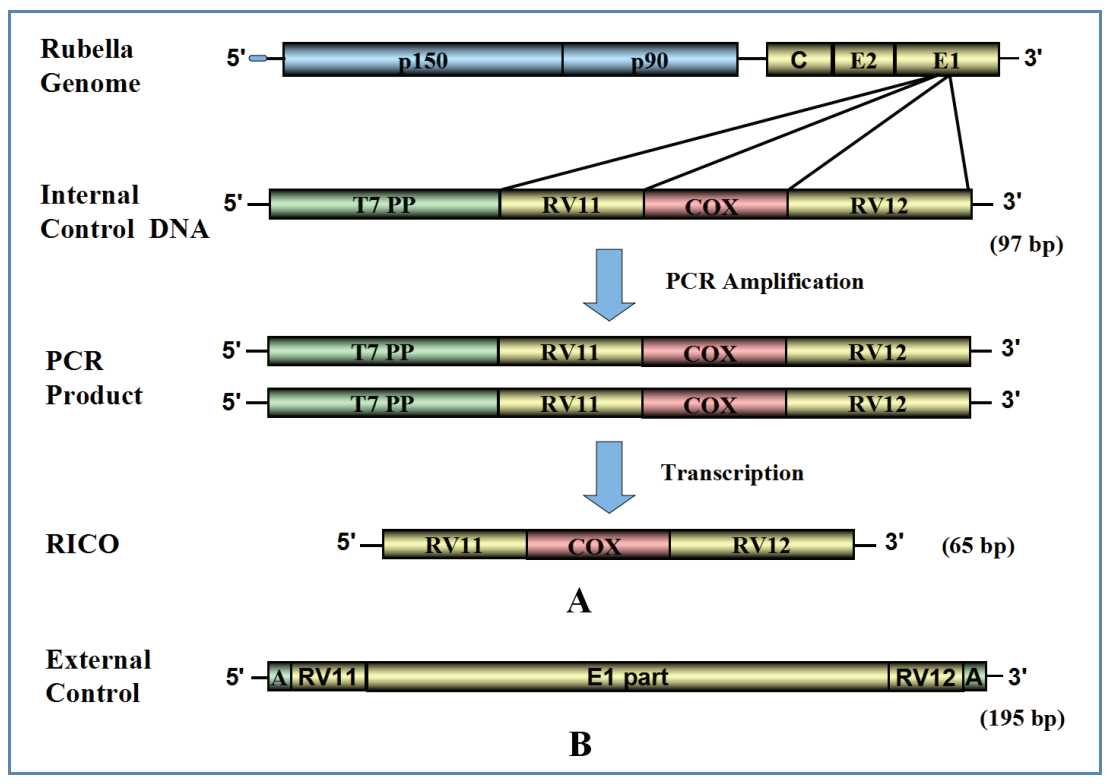

Figure 3. Production principal of RICO and design of target synthetic DNA. A: Rubella genome has 9,762 nucleotides and encodes two nonstructural polypeptides (p150 and p90) and three structural polypeptides $(\mathrm{C}, \mathrm{E} 2$, and E1). T7 PP is a region for the recognition of $\mathrm{T} 7$ RNA polymerase. RV11, COX, and RV12 are the target regions for the forward primer, COX probe (designed based on potato cytochrome oxidase gene sequence with modification) and reverse primer, respectively. B: Target synthetic DNA designed based on rubella E1 gene. Both ends are added with five nucleotides to enhance primer effectiveness. RV11, E1 part, and RV12 will compose the $195 \mathrm{bp}$ amplicon during the PCR process.

Acid kit, RNA from those viruses can also be obtained. Even so, both viruses do not give positive results in this RT-qPCR system (Figure 1). Probes specific to target and internal control were successfully read by green and yellow channels of Rotor-Gene Q instrument (Figure 2).

RICO was produced by the transcription of ICO as outlined in Figure 3. The purity of RICO was confirmed as no

Table 2. Ct ratio between target synthetic DNA and RICO.

\begin{tabular}{cccc}
\hline $\begin{array}{c}\text { Target Synthetic } \\
\text { DNA Copy } \\
\text { Number }\end{array}$ & E1 gene & Internal Control & \\
\cline { 2 - 3 } & Ct Ratio \\
100,000 & 19.13 & 38.11 & 0.5 \\
10,000 & 22.59 & 35.74 & 0.63 \\
1,000 & 26.1 & 35.84 & 0.73 \\
100 & 29.66 & 34.79 & 0.85 \\
10 & 33.09 & 35.48 & 0.93 \\
5 & 33.99 & 35.43 & 0.96 \\
\hline
\end{tabular}

increase of fluorescence was seen in the absence of reverse transcriptase, as well as no band on the gel electrophoresis (data not shown). Primer competition between target synthetic DNA and RICO was indicated by a decrease in the ratio between $\mathrm{Ct}$ of RICO and $\mathrm{Ct}$ of target synthetic DNA at higher concentration of target synthetic DNA, as shown in Table 2. RICO amplification with target synthetic DNA was detectable in the presence of lower concentration of target synthetic DNA but not in the higher concentration.

This PCR system could detect up to 5 copies/ $\mu$ l of target synthetic DNA. The precision of this assay was assessed by calculating the $\mathrm{CV}$ for the $\mathrm{Ct}$ values experimentally determined (Table 1). Experimental variability was higher in lower external control input. Within run variation contributed the largest $\mathrm{CV}$ for this assay.

Spike recovery was performed to determine whether the RNA and DNA detection is affected by the difference between the diluent used to prepare the Trimovax vaccine or target synthetic DNA and the amniotic fluid matrix. The recovery of target synthetic DNA from amniotic fluid was almost $100 \%$. The recovery of rubella RNA in Trimovax vaccine from amniotic fluid is not as good as the recovery of DNA in target synthetic DNA.

Table 3. Precision of the test.

\begin{tabular}{cccccccccccc}
\hline \multirow{2}{*}{$\begin{array}{c}\text { Copy } \\
\text { Number }\end{array}$} & $\begin{array}{c}\text { Vithin Run } \\
\text { Variation }\end{array}$ & \multicolumn{2}{c}{$\begin{array}{c}\text { Between Run } \\
\text { Variation }\end{array}$} & \multicolumn{2}{c}{$\begin{array}{c}\text { Lot-to-lot } \\
\text { Variation }\end{array}$} & $\begin{array}{c}\text { Between Scientist } \\
\text { Variation }\end{array}$ & $\begin{array}{c}\text { Total } \\
\text { Variation }\end{array}$ \\
\hline & Mean Ct & $\mathbf{C V}$ & Mean Ct & $\mathbf{C V}$ & Mean Ct & $\mathbf{C V}$ & Mean Ct & CV & Mean Ct & CV \\
\hline 5 & 34.16 & $2.71 \%$ & 34.27 & $1.20 \%$ & 34.04 & $1.62 \%$ & 33.94 & $1.59 \%$ & 33.99 & $1.59 \%$ \\
10 & 33.4 & $2.11 \%$ & 33.08 & $1.74 \%$ & 33.15 & $1.75 \%$ & 33.14 & $1.97 \%$ & 33.09 & $1.83 \%$ \\
100,000 & 19.21 & $0.65 \%$ & 19.20 & $0.52 \%$ & 19.19 & $0.44 \%$ & 19.09 & $0.57 \%$ & 19.13 & $0.65 \%$ \\
\hline
\end{tabular}


Table 4. Recovery of RNA and DNA from amniotic fluid.

\begin{tabular}{|c|c|c|c|c|c|}
\hline & & \multirow[t]{2}{*}{ AF+ Trimovax } & \multirow{2}{*}{$\begin{array}{l}\text { AF }+ \text { Excon } \\
5 \text { copies } / \mu l\end{array}$} & \multirow{2}{*}{$\begin{array}{l}A F+\text { Excon } \\
10 \text { copies } / \mu \mathrm{I}\end{array}$} & \multirow{2}{*}{$\begin{array}{c}\text { AF }+ \text { Excon } \\
100,000 \text { copies } / \mu\end{array}$} \\
\hline & & & & & \\
\hline \multirow{2}{*}{$\begin{array}{c}\text { PCR } \\
\text { Result }\end{array}$} & Copies & 4 & 19 & 33 & 427,198 \\
\hline & Log copies & 1 & 1 & 2 & 6 \\
\hline \multirow{2}{*}{$\begin{array}{c}\text { Teoritical } \\
\text { Result }\end{array}$} & Copies & 6 & 20 & 40 & 400,000 \\
\hline & Log copies & 1 & 1 & 2 & 6 \\
\hline \multicolumn{2}{|c|}{ Recovery (\%) } & 77.37 & 98.29 & 94.79 & 100.51 \\
\hline
\end{tabular}

\section{Discussion}

$\mathrm{RV}$ is a teratogenic virus which is able to infect and cause damage to the fetus $(1-5,7)$. One of several factors that influence the ability of viruses to cross the placenta is the mother's immune status against the specific virus. In general, secondary infection and reinfection are less destructive than a primary infection as the mother has already developed immunity prior to the secondary infection (2). Primary and secondary infections can be distinguished by the laboratory testing of maternal immune status. In addition to the examination of the mother, it is important to look for the possibility of fetal infection and to assess the fetal damage and prognosis. For this purpose, prenatal laboratory testing is required so that clinical decisions such as drug treatment, termination of pregnancy or intrauterine $\operatorname{IgG}$ transfusion can be considered.

Several methods can be used to assess viral infections in pregnancy. These methods can be divided into serology and virus detection. Virus detection is preferred over serological tests due to its ability to directly detect the presence of virus in samples. Virus detection can be done by virus isolation in tissue culture, direct antigen, shell-vial assay, RT-PCR, RT-nPCR, real-time PCR/RT-PCR, in situ hybridization, in situ PCR $(2,10)$. Although virus detection is used primarily for prenatal diagnosis, serological tests are still needed to support the results of virus detection and vice versa.

Several groups have described molecular-based methods to detect rubella RNA from amniotic fluid and other samples. Bosma et al. performed reverse transcription nested PCR to detect rubella RNA from seven chorionic villus (CVS), three amniotic fluid (AF), and two fetal blood samples (11). Revello et al. used the same method but with different sets of primer to detect rubella RNA from nine AF, one CVS, and four fetal peripheral blood mononuclear cell (MN) samples (12). Two-step RT-PCR was used by Mace et al. to detect rubella RNA in $110 \mathrm{AF}$ and 23 fetal blood samples (13). On 2007, an investigation of rubella and congenital rubella syndrome was done using two blockbased RT-PCR and a two-step RT-qPCR (14).

We adopted the one-step RT-qPCR described by Abernathy et al. to detect rubella RNA (15). One-step real-time RT-PCR was chosen in this study for its ability to enable reverse transcription, amplification, and detection of viral nucleic acids simultaneously in a single tube. This system reduces the possibility of contamination, simplifies work-flow, and enables faster testing. The use of probes in this system resulted in a more specific examination. It also allows quantification of viral nucleic acid. In the previous study, primer and probe used in this study had successfully detected rubella RNA from oral fluid and throat swabs. However, they have not been used to detect rubella RNA from amniotic fluid. In this study those primers and probe managed to detect rubella RNA from vaccine spiked in negative amniotic fluid.

The limit detection of the test reported before was 12 copies of RV RNA (15). Though we managed to obtain at least 5 copies synthetic DNA/ $\mu$, it was not comparable with the result from previous study as it was measured using DNA instead of RNA. Another study managed to detect 2 copies of rubella cDNA using two-step RT-qPCR (14). This discrepancy could be caused by several factors, one of which was the size of the resulting amplicon. In that study, the resulting amplicon was $56 \mathrm{bp}$, which was much shorter than the amplicon size in our study. Another contributing factor was the usage of two-step RT-PCR that allowed them to optimize the reverse transcription step and increase the sensitivity of the assay. The specificity of the primers and probes was checked using the Basic Local Alignment Search Tool (BLAST) at http://www.ncbi.nlm.nih.gov/ BLAST. It was also confirmed by the PCR result on agarose gel and amplification curve.

Internal control is crucial to control the whole process, from extraction to amplification and detection. A competitive 
RNA internal control has been introduced to monitor this assay system. It was able to distinguish negative results due to inhibition or human error from true-negative results.

DNA internal control can be used to monitor the amplification efficiency, but in RT-PCR it could not be used to control the reverse transcription efficiency. RNA internal control was used in this study, as it enabled the monitoring of reverse transcription efficiency and PCR efficiency. The reference publication of this study also used RNA internal control which is a 150 -bp region of $\beta$-actin gene (15). In their study, the target and internal control were amplified using a different primer set for each. The $\beta$-actin gene was present in the specimen, thus this internal control was used to control the quality of RNA extraction as well. It was also expected to be able to control the reverse transcription step. However its ability to control the amplification efficiency was still questioned as it might not accurately reflect amplification of the primary target due to differences in the primer sets.

There are several approaches to the production of RNA internal control. The first approach is by using the normal cellular gene or housekeeping genes sequence (1617). This method will need different primers to amplify the internal control. The other approaches are by introducing a mutation to the target amplicon, deletion or insertion of sequences into the target amplicon, or splicing of the target primer sequences onto a nonhomologous DNA sequence (18-19). The RNA internal control was produced by modifying sequences between the recognition primer sites (20). First, we designed DNA sequence which contained a T7 RNA polymerase promoter sequence at the 5' end, followed by forward primer sequence, probe binding region, and the complementary sequence of reverse primer at the 3 ' end. This double-stranded synthetic DNA was amplified and transcribed into RNA using T7 RNA polymerase. The produced RNA was purified in order to eliminate the remaining DNA. Using this approach the production of RNA internal control would be faster than the production of internal control within a plasmid. Though inserting the target sequence into plasmid could improve the stability of internal control, this approach consumes more production time as it needs cultivation of bacterial cells to multiply the plasmids and further steps to recover the plasmid and to produce the RNA internal control (19).

Due to the competition between target and internal control for the primers, it is important to determine the optimal amount of internal control concentration in the assay. The addition of internal control could reduce the sensitivity of the assay therefore the amount of internal control in the assay should be as low as possible. Internal control concentration used in this study is the concentration at which internal control can be amplified in a reaction containing 5 copies $/ \mu$ l of DNA target synthetic DNA without disrupting the sensitivity of the assay. Agarose gel electrophoresis results indicate that internal control was still detected at a concentration of 10,000 copies of target synthetic DNA. The amplification curve of internal control was still detected at a concentration of 100,000 of target synthetic DNA.

The assay showed a good reproducibility with a total Ct coefficient of variation less than 3\% for all parameters. Our result is comparable with the reproducibility which obtained by Zhau et al. who also used RT-qPCR to detect rubella RNA. This group used RV-specific PCR amplicon as a standard in their study. They obtained coefficient of variation range from 1.25 to $3.58 \%$ for $2.75 \times 10^{2}$ to $2.75 \times 10^{7}$ copies/ml of standard (21). In our study the within run variation accounted the greatest variation among the other variations. Within run variation occurs likely due to error in dilution and pipetation. This means that the operator, run time, and lots different did not significantly affect the reproducibility of the assay.

The primers used in this study have not been used for rubella RNA detection in amniotic fluid. However, spike recovery was close to $100 \%$ in all of target synthetic DNA with various concentrations. This result indicated that amniotic fluid constituents did not interfere with the process of extraction, amplification and detection on the test. Although clinical sample was not available during this study, the good recovery result confirms the usefulness of this assay in clinical setting. The complexity of Trimovax Merieux vaccine content is suspected to be the cause of poor rubella RNA recovery from amniotic fluid. This vaccine is available in lyophilisates containing RNA genomes of three types of viruses in human albumin.

The design and result of this study demonstrate comparable performance between the assay of this study with the commercially available kit. Highly sensitive PCR assays, detecting 3-10 copies of RV RNA, are required for PD as fetal specimens generally contain low RV copy numbers (10). This assay managed to detect up to 5 copies synthetic DNA/ $\mu 1$. The RV11 and RV12 primer pairs were designed to amplify the E1 coding region. This is beneficial as other RT-qPCR protocols targeting the E1 gene have been used successfully for prenatal diagnosis $(12,13)$. Though the Rubella Real-TM Qual (Sacace Biotechnologies, Italy) can be used for rubella RNA qualitative detection in various samples including amniotic fluid and show a high sensitivity of not less than 400 copies $/ \mathrm{ml}$, this kit targeted p150 which is not a common gene target for rubella RNA detection (22). 
Another kit from Shanghai ZJ Bio-Tech Co., Ltd., known as Rubella Virus Real Time RT-PCR Kit (Liferiver, China) also has a high sensitivity but is designed to detect RV in nasal and pharyngeal secretions, not for amniotic fluid which is recommended as the specimen for prenatal diagnosis of rubella infection (23). Overall, this method can be developed into a method for the diagnosis of rubella infection during pregnancy. But clinical specimens evaluation is needed to support this purpose.

\section{Conclusion}

RT-qPCR is successfully used for the detection of RV RNA in vaccine and synthetic nucleic acid. One-step RTPCR system eliminates manual reverse transcription thus simplify and accelerate detection method. With its high sensitivity, good precision and recovery, this method offers as a means to improve the diagnosis of congenital rubella infection in developing countries like Indonesia.

\section{References}

1. Webster WS. Teratogen update: congenital rubella. Teratology. 1998; 58 : 13-23.

2. Mendelson E, Aboudy Y, Smetana Z, Tepperberg M, Grossman Z. Laboratory assessment and diagnosis of congenital viral infections: rubella, cytomegalovirus (CMV), varicella-zoster virus (VZV), herpes simplex virus (HSV), parvovirus B19 and human immunodeficiency virus (HIV). Reprod Toxicol. 2006; 21: 350-82.

3. Saraswathy TS, Rozainanee MZ, Asshikin RN, Zainah S. Congenital rubella syndrome: a review of laboratory data from 2002 to 2011. Southeast Asian J Trop Med Public Health. 2013; 44: 429-35.

4. Best JM. Rubella. Semin Fetal and Neonatal Med. 2007; 12: 182-92.

5. Robertson SE, Featherstone DA, Gacic-Dobo M, Hersh BS. Rubella and congenital rubella syndrome: global update. Rev panam Salud Publica. 2003; 14: 306-15.

6. World Health Organization. WHO vaccine-preventable diseases: monitoring system. 2013 global summary; 2013 [updated 2013 Oct 20; cited 2013 Des 13]. Available from: http://apps.who.int/.

7. Banatvala JE, Brown DW. Rubella. Lancet. 2004; 363: 1127-37.

8. Chen MH, Icenogle J. Molecular virology of rubella virus. In: Banatvala JE, Peckham C, editors. Perspectives in medical virology, Vol. 15. Rubella viruses. Amsterdam: Elsevier; 2007. p.19-37.

9. World Health Organization. Weekly epidemiological record: July 2011. WHO 2011; 86: 301-16. Available from: http://www.who.int/ wer/2011/wer8629.pdf

10. Best JM, Enders G. Laboratory diagnosis of rubella and congenital rubella. In: Banatvala JE, Peckham $\mathrm{C}$, editors. Perspectives in medical virology, Vol. 15. Rubella viruses. Amsterdam: Elsevier; 2007. p.39-77.

11. Bosma TJ, Corbett KM, Eckstein MB, O'Shea S, Vijayalakshmi P, Banatvala, et al. Use of PCR for prenatal and postnatal diagnosis of congenital rubella. J Clin Microbiol. 1995; 33: 2881-87.

12. Revello MG, Baldanti F, Sarasini A, Zavattoni M, Torsellini M, Gerna G. Prenatal diagnosis of rubella virus infection by direct detection and semiquantitation of viral RNA in clinical samples by reverse
transcription-PCR. J Clin Microbiol. 1997; 35: 708-13.

13. Macé M, Cointe D, Six C, Levy-Bruhl D, du Châtelet IP, Ingrand D, et $a l$. Diagnostic value of reverse transcription-PCR of amniotic fluid for prenatal diagnosis of congenital rubella infection in pregnant women with confirmed primary rubella infection. J Clin Microbiol. 2004; 42: 4818-20.

14. Jin L, Thomas B. Application of molecular and serological assays to case based investigations of rubella and congenital rubella syndrome. J Med Virol. 2007; 79; 1017-24.

15. Abernathy E, Cabezas C, Sun H, Zheng Q, Chen MH, CastilloSolorzano $\mathrm{C}$, et al. Confirmation of rubella within 4 days of rash onset: comparison of rubella virus RNA detection in oral fluid with immunoglobulin $\mathrm{M}$ detection in serum or oral fluid. J Clin Microbiol. 2009; 47: 182-88.

16. Rosenstraus M, Wang Z, Chang SY, DeBonville D, Spadoro JP. An internal control for routine diagnostic PCR: design, properties, and effect on clinical performance. J Clin Microbiol. 1998; 36: 191-97.

17. Jain M, Nijhawan A, Tyagi AK, Khurana JP. Validation of housekeeping genes as internal control for studying gene expression in rice by quantitative real-time PCR. Biochem Biophys Res Commun. 2006; 345: 646-51.

18. Gibson UE, Heid CA, Williams PM. A novel method for real time quantitative RT-PCR. Genome Res. 1996; 6: 995-1001.

19. Hoorfar J, Malorny B, Abdulmawjood A, Cook N, Wagner M, Fach P. Practical considerations in design of internal amplification controls for diagnostic PCR assays. J Clin Microbiol. 2004; 42: 1863-68.

20. Burggraf S, Olgemöller B. Straightforward procedure for internal control of real-time reverse transcription amplification assays. Clin Chem. 2005; 51: 1508-10.

21. Zhao LH, Ma YY, Wang H, Zhao SP, Zhao WM, Li H, et al. Establishment and application of a TaqMan real-time quantitative reverse transcription-polymerase chain reaction assay for rubella virus RNA. Acta Biochim Biophys Sin (Shanghai). 2006; 38: 731-6.

22. Sacace Biotechnologies. Rubella Real-TM Qual Handbook. 2011. DNA GDANSK 2011; [updated 2011 Nov 11; cited 2014 May 26]. Available from: http://www.dnagdansk.com/.

23. Liferiver. Rubella Virus Real Time RT-PCR Kit User Manual. Bio SB 2012; [updated 2012 Jul 1; cited 2014 May 26]. Available from: http://www.biosb.com/. 